\title{
Undergraduate Students' Perceptions of the Mathematics Courses Included in the Primary School Teacher Education Program
}

\author{
Mehmet Koray Serin * \\ Kastamonu University, TURKEY
}

\author{
Semahat Incikabi \\ Kastamonu University, TURKEY
}

Received: September 28, 2017 - Revised: October 10, 2017 • Accepted: October 12, 2017

\begin{abstract}
Mathematics educators have reported on many issues regarding students' mathematical education, particularly students who received mathematics education at different departments such as engineering, science or primary school, including their difficulties with mathematical concepts, their understanding of and preferences for mathematical concepts. This study aimed to investigate the opinions of primary-school teacher education students in terms of their perceptions of difficulty level of the mathematics courses, change in their achievement, if there is any, and interest in mathematics after completing these courses, and factors affecting their achievement and interest level in these courses. Being qualitative in nature, this study was a case study. The data were analyzed using the content analysis and descriptive methods. According to the results, most students stated that they faced mathematics course content with unexpected level of difficulty. After taking basic mathematics courses, the percentage of students with decreased level of interest and achievement in mathematics was found higher than the students who experienced an increase in their interest and achievement. Students underlined such significant factors for the change of their interest and achievement in mathematics as prior knowledge, lecturer(s), and content coverage. Finally, most of the students viewed mathematics courses as a beneficiary tool for their professional development.
\end{abstract}

Keywords: Primary school teacher education, undergraduate students, mathematics courses, mathematics education.

To cite this article: Serin, M. K., \& Incikabi, S. (2017). Undergraduate students' perceptions of the mathematics courses included in the primary school teacher education program. European Journal of Educational Research, 6(4), 541-552. doi: 10.12973/eujer.6.4.541

\section{Introduction}

Unlike the old and widely accepted approach of seeing mathematics as a discipline full of meaningless rules and calculations, nowadays mathematics can be defined as a science consisted of pattern and order (Van De Walle, Karp \& Bay-Williams, 2010). At the same time, mathematics is a fundamental tool for not only solving scientific problems but also solving issues encountered in daily life. Because of this significance, mathematics has its place in every level of education, from pre-school to high school and universities (Baykul, 2014). The question of "Why mathematics should be instructed as a course?" can be answered in different ways. Generally speaking, four reasons can be counted to explain why mathematics is taught in schools. Students who took mathematic lessons learn to appreciate mathematics, gain skills such as reasoning specific to the mathematics, use mathematics as a way of communication and gain problem solving skills (Baki, 2014). Despite the called significance of mathematics courses, especially in the university level, basic mathematics courses are among the courses that students failed more, especially in the departments like engineering, sports, statistics (Zevenbergen, 2001; Suresh, 2002; Gupta, Harris, Carrier \& Caron, 2006; Eng, Li Li \& Julaihi, 2013; Harris, Black, Hernandez-Martinez, Pepin, Williams \& with the TransMaths Team, 2015).

Moreover, studies also underlined that students from engineering (Flegg, Mallet \& Lupton, 2012), science education (Britton, New, Sharma, \& Yardley, 2005) and primary school teacher education departments (Kandemir, 2007) have difficulties in transferring their mathematics knowledge to their own field; they could not achieve the required level of mathematical knowledge for understanding and interpreting mathematics concepts. The interesting point here is not the overall link between ability in mathematics and the ability to apply mathematics in different situations, but the variety of abilities students show when they transfer their demonstrated knowledge in mathematics to another area (Britton et al., 2005).

In general, many universities offer basic mathematics as a compulsory course during the first year of undergraduate education (Grootenboer, 2003). Most of the time, mathematics courses in any department, including primary school

\footnotetext{
* Corresponding author:

Mehmet Koray Serin, Kastamonu University, Faculty of Education, Turkey,

Email: mkserin@kastamonu.edu.tr
} 
education, science education or engineering have been instructed by the members of mathematics departments and this inevitably makes service teaching a significant part of the teaching practice of mathematics departments all around the world. While university lecturers' teaching of advanced courses has gained little attention in mathematics education literature, service teaching has received even less attention (Weber, 2004). In literature, some studies focused on this situation and its role in mathematics education. As an example, Bingolbali and Ozmantar (2009) conducted research about mathematics lessons given to non-mathematics majors by instructors from mathematics department. According to research results, lecturers and students having incongruity on main topics like needs, demands, expectations, difference between departments, obligations and also curriculum and course schedule. Kent and Noss (2001) reconsider the topic of service mathematics and suggest a reconsideration of teaching mathematics to the students of engineering departments in such a way that reflects the changes coming about in the actual practice of the professional engineering on the basis of the technological innovations. In addition, Sutherland and Pozzi's (1995) also pay attention to the changes in the mathematical backgrounds of the students accepted to study in engineering departments and suggests a reconsideration of the service teaching for these students.

In recent years, affective approach is getting more and more interest than cognitive approach in the mathematics education field. As Philippou and Christou stated (1998) affective variables like opinion, belief, attitude about mathematics have important role on developing teaching practices. Similarly, Thompson (1992) underlines teachers' beliefs, attitudes and perceptions not only makes primary contribution for shaping teaching practices, but also affecting student's interest, attitude, belief and success. Affective studies relating mathematics education field generally focused on mathematics achievement and beliefs on teaching-learning mathematics (Beswick, 2012; Boz, 2008; Cooke \& Hurst, 2013; Schuck, 1997), attitudes towards mathematics (Charalambous, Panaoura \& Philippou, 2009), values in mathematics education (Clarkson, Bishop, FitzSimons \& Seah, 2000), and anxiety towards mathematics (Rayner, Pitsolantis \& Osana, 2009).

Primary-school undergraduate students receive content knowledge from mathematics courses in their faculties, and develop positive or negative attitudes and beliefs towards mathematics lessons and learning process of it. It is expressed that conditions like content knowledge, attitude, belief, anxiety have strong effects on teaching practices (Charalambos, Philippou \& Kyriakides, 2002; Ernest, 2000; Uusimaki \& Nason, 2004). While these situations are underlined for mathematics courses in particular, they can be generalized for teaching profession in general as well. It is believed that undergraduate students' perceptions, attitudes and beliefs on mathematics and mathematics courses have influence on primary-school students' perceptions and attitudes towards mathematics and mathematics courses. Studies show that individuals' positive or negative attitude towards mathematics develops in childhood and primaryschool education (Alkan, 2009; Gallagher \& Kaufman, 2005; Guner, 2013) and teacher's beliefs and attitudes effecting student's beliefs and attitudes (Ernest, 1989a; Ernest, 1989b; Midgley, Feldlaufer \& Eccles, 1989; Zevenbergen, 2005).

Mathematics educators have reported on many issues regarding primary school students' mathematical education including their difficulties with mathematical concepts, their understanding of and preferences for mathematical concepts, their changing mathematical background at entry to departments over the years and problems arising from this and their attitudes and approaches to mathematics. Common to all these studies is the appreciation that mathematical skills of those students entering university are decreasing and that they lack a fundamental understanding of mathematical concepts. This, alongside many other factors, it is argued, affects their mathematical attainment in primary school education courses (Bingolbali, Monaghan \& Rober, 2007).

Based on this literature, the current study aimed to investigate the perceptions of primary-school teacher education students in terms of their views and expectancies regarding difficulty level of the mathematics courses, change in their interest in mathematics after completing these courses, if there is any, factors affecting their achievement and interest level in these courses and opinions regarding contribution of undergraduate mathematics courses to their professional development. Being in line with the targeted purposes, the following questions were aimed to be answered:

1. How does it changed, if it happens, primary-school undergraduate students' perception of difficulty level of mathematics courses after they completed the courses?

2. Are there any differences on interest of primary-school undergraduate students in mathematics after they completed the courses?

3. Which factors do primary-school undergraduate students assert for their success or failure in mathematics courses?

4. How primary-school undergraduate students evaluate possible contributions of mathematics courses to their professional development?

\section{Methodology}


In this study, the opinions of college students in the primary school teacher education department were used in order to determine their views about mathematics content in their program in terms of their proficiency and their expectations from the content. Being qualitative in nature, this study was designed as a case study. In a case study, a researcher is expected to examine a situation within its own contextual boundaries, limited by time and activity, and s/he collects detailed information (Merriam 1998; Yin 2003). The case that was investigated in the current research involved undergraduate students' expectations from mathematics courses taught in the primary school teacher education program at a state university in Turkey.

\section{Study Group}

The participants of the study consisted of a total 105 college students (in their first-year in university) from the department of primary school education. All the participants were voluntarily participated to the study. The demographics of the participants were collected through a questionnaire that was developed by the researcher to collect data on undergraduate students' demographics and the questionnaire had been checked by an expert before conducted. According to results, age of the participants ranged from 17 to 20 with an average of 17.8. In general, their experience with mathematics course was limited to the college courses titled "Basic Mathematics I" and "Basic Mathematics II.

\section{Data Collection}

Two instruments were used to collect data in the present study. The first one was the demographics questionnaire that included questions about undergraduate students' age, gender and mathematics lessons they took. The second instrument was the open-ended questionnaire that was developed by the researchers and checked by an external expert before the implementation. Semi-structured open-ended questionnaires enable respondents to spontaneously and authentically reflect their points of view (Arnon \& Reichel 2007). In line with the research question listed above, the questionnaire included four questions that investigate undergraduate primary school students' perceptions regarding their expectancy and their actual feeling about the difficulty level of the basic mathematics courses, their attitudes towards mathematics before and after the courses, reasons for failure or success in the mathematics courses, usefulness of mathematics in primary school teaching. The undergraduate primary-school students were given adequate time (approximately 45 minutes) to respond to the questions.

\section{Data Analysis}

The data were analyzed using the content analysis and descriptive methods. First, all of the responses provided were listed. Then, the written responses were classified according to similar categories and sub-categories. These categories and sub-categories were determined gradually. The frequencies and percentages of the sub-categories were provided and supported by qualitative data that were quotas from the undergraduate primary-school students' views. Two experts from the field of mathematics education independently coded data. Agreement rate between the coders reliability was calculated as 94\% according to Miles and Huberman (1994)'s formula. The items that caused disagreement between the coders were discussed until an agreement has been reached. Some pre-service teachers' answers and reasons were coded under more than one category. Hence the total frequencies of the attributions presented in the results might be more than the actual number of the participants (i.e., 105).

\section{Findings / Results}

Table 1 shows a classification of undergraduate primary-school students' views about expectations on difficulty level of the mathematics courses before their enrolment and experiences about difficulty level after courses. 
Table 1. Undergraduate primary school students' views about expectations on difficulty level of the mathematics courses

\begin{tabular}{|c|c|c|c|c|}
\hline Expectations & Experience & Reasons & $\mathbf{f}$ & $\%$ \\
\hline No expectation & & & 5 & 5 \\
\hline \multirow{5}{*}{$\begin{array}{l}\text { I expect it to } \\
\text { be easy }\end{array}$} & \multirow{5}{*}{ Difficult } & Content coverage & 20 & 17 \\
\hline & & Lecturer & 8 & 7 \\
\hline & & Prior knowledge & 3 & 3 \\
\hline & & Student & 1 & 1 \\
\hline & & Total & 32 & 28 \\
\hline \multirow{13}{*}{ As I expected } & \multirow[t]{4}{*}{ Easy as I expected } & & 24 & 20 \\
\hline & & Prior knowledge & 16 & 14 \\
\hline & & Preparation & 4 & 3 \\
\hline & & Positive attitude & 4 & 3 \\
\hline & \multirow[t]{3}{*}{ Difficult as I expected } & & 19 & 16 \\
\hline & & The ongoing failure & 11 & 9 \\
\hline & & Prior knowledge & 8 & 7 \\
\hline & \multirow[t]{6}{*}{ Normal as I expected } & & 14 & 12 \\
\hline & & Unchanging content & 5 & 4 \\
\hline & & Spiral structure & 5 & 4 \\
\hline & & Balanced content & 2 & 2 \\
\hline & & Achievable content & 2 & 2 \\
\hline & & Total & 57 & 48 \\
\hline \multirow{4}{*}{$\begin{array}{l}\text { I expect it to } \\
\text { be difficult }\end{array}$} & \multirow{4}{*}{ Easy } & Content coverage & 20 & 17 \\
\hline & & Student & 2 & 2 \\
\hline & & Total & 22 & 19 \\
\hline & & Overall & 116 & 100 \\
\hline
\end{tabular}

Note: As mentioned earlier, some pre-service teachers' reasons coded under more than one category. Hence the total frequencies of the attributions were more than 105.

Analysis of the Table 1 yielded that only a small percentage of the students (5\%) had no expectation relating the difficulty level of the mathematics courses. Moreover, about half of the students (48\%) had expected the mathematics courses as to be easy while 35 percent of them had expected mathematics courses as to be difficult. That is, on the one hand, $28 \%$ had expected the course easy but found it difficult in practice and $20 \%$ had expected the course easy and found it easy in practice as well. On the other hand, $16 \%$ had expected the course difficult and found it difficult in practice while $19 \%$ had expected it difficult but found it easy in practice. According to the table, 12 percentages of the undergraduate primary school students carried the expectation of a "normal" course before their enrolment in the mathematics courses.

In addition, according to the table, about half of the primary-school teacher education students (48\% in total) said that their experiences in terms of the difficulty level of the course met their expectations. Moreover, 20 percentages of the students expressed that undergraduate mathematics courses were as easy as they had expected while 16 percent of them declared that the courses were difficult as they had expected. They have already had the same content in previous years and because of that they faced easy content as they expected. Moreover, twenty-eight percentages of the students who thought that the course would be easy before they took it faced a more difficult course when they took it. However, only 19 percentages of the students found mathematics courses easier than their expectation.

The students also provided various reasons for their experiences relating difficulty level of the mathematics courses after their enrollment in these courses. Their prior knowledge in mathematics courses was an important reason for students to regard content difficulty level of the courses as difficult or easy. One student (s62), who expected and experienced the mathematics courses as to be easy, stated "since graduated from a science high school, I knew that I won't have any difficulties. Before I took this class, I checked topics that included in course and I got an idea about it. I have seen and already knew all of these topics." Another student (s9) blamed his past knowledge (education) with the statement "since I graduated from vocational high school, I could not build a strong basis for basic mathematics."

Content covered in the mathematics courses was another reason for the students for their attribution of the perceived difficulty level of the courses. One student (s47) who thought that the course would be easy before s/he took it, but $\mathrm{s} /$ he faced a more difficult course, stated "the reason why it is more difficult than I expected is this mathematics course is very hard for primary-school students. We studied topics which are not even included in KPSS exam. Trigonometry, 
functions are not the topics you can teach primary-school students." Contrary to this, while expecting to face a difficult course, some primary-school undergraduate students (17\%) finds the content of the mathematics courses basic and easy because they had more difficult mathematics courses during their high school education. One student explained this as: "before I came here my expectation was to study all of the topics in mathematics course but it did not happen, we did not go deep, we did not focus on contents" (s23). At the same time, some students explained that because of their negative past experiences with mathematics courses, they were prejudiced and that is why they expected a difficult content and they faced it. For example, s31 stated that "since I already lost my hope about mathematics, I knew that I will face the same issue here. Nothing has changed."

Table 2 shows the distribution of possible changes in primary-school undergraduate students' interest in mathematics after taking the course and the reasons for the changes.

Table 2. Undergraduate primary school students' perceptions of change in their interest towards mathematics after completing mathematics courses

\begin{tabular}{|c|c|c|c|}
\hline Change of interest & Reasons & $\mathbf{f}$ & $\%$ \\
\hline Changed & & 45 & 41 \\
\hline \multicolumn{4}{|l|}{ My interest decreased } \\
\hline & Experienced failure & 16 & 15 \\
\hline & Lecturer & 12 & 11 \\
\hline & Content & 5 & 4 \\
\hline \multicolumn{4}{|l|}{ My interest increased } \\
\hline & Ongoing success & 10 & 9 \\
\hline & Lecturer & 2 & 2 \\
\hline No Change & & 64 & 59 \\
\hline \multicolumn{4}{|l|}{ I still don't like it } \\
\hline & Ongoing and continuing failure & 16 & 15 \\
\hline & Negative attitude & 6 & 5 \\
\hline & Content & 2 & 2 \\
\hline \multicolumn{4}{|l|}{ I still like it } \\
\hline & Positive attitude & 13 & 12 \\
\hline & Ongoing and continuing success & 12 & 11 \\
\hline & Positive interest & 9 & 8 \\
\hline & Prior knowledge & 4 & 4 \\
\hline & Lecturer & 2 & 2 \\
\hline Overall & & 109 & 100 \\
\hline
\end{tabular}

According to the table, 59 percentages of the students declared no change in their interest in mathematics while 41 percent of them stated (negative or positive) change in their interest. By analyzing data from Table 2, it is seen that about one-tenth of the students have their general interest towards mathematics increased while about one-third of them have stated negative change in their interest in mathematics after they finish Basic Mathematics I and Basic Mathematics II courses.

Among the reasons for negative change in their interest towards mathematics were their failure in the course, lecturer of the course(s) and content coverage of the courses while passing (success) from the course and lecturer were the main reasons for the positive gain in the interest towards mathematics. Accordingly, s21 stated content difficulty of the courses and lecturer's contribution to his success with the statement "While I already had insufficient knowledge about topics, they became harder and harder when we passed them. This difficulty could be eliminated by instructor's teaching methods." A negative view regarding the content of the course can be seen in s54' s response: "I think while topics in the Mathematics I course in first term were easy, the topics in Mathematics II were very difficult."

Students explain cause of this change as their experience on the increasing success feelings they had. Accordingly, s72 explained this as: "when I see that I can even do mathematics a bit, of course, my interest on mathematics increased. Even thought was a little bit of, I lost my prejudices". In opposite of this situation, students who have decreased interest in mathematics explain cause of this as when they are experience increased feeling of failure, they have their interest in mathematics decreased (15\%). As an example, s96 made the following explanation: "before I came to this school I have some interest in mathematics. While I worked hard for exams, I got low scores and this diminished my interest in mathematics. When it comes to math, it almost disgusts me, literally."

Significant amount of student from focus group, 59\%, stated that their interest level on mathematics did not change after they took the mathematics course. Among them, 22 percent stated that they did not like mathematics before 
taking the class and this did not change after it, other $37 \%$ said the opposite, they liked mathematics before taking the course and it did not change afterwards. In both situations, students explain their cause as their ongoing mathematics experiences; while students with negative opinions underlined ongoing failure (15\%), students with positive opinions underlined ongoing success and their positive attitudes towards mathematics. One student (s103) explained his interest in mathematics with the statement "I have not any fear of mathematics, I could do it and this cause me to study harder on it. I am becoming happier when I see my success. I loved it and I still love it" while another (s71) blamed herself and continuing failure in mathematics with the words "I guess I will never like Mathematics because I can't understand it. I try my best to understand it but I still fail. Poets, reading books are way more satisfying than mathematics problems for me." Some of the students, $12 \%$, stated that they love mathematics all the time and this did not change after they finish mathematics course. S94 made this statement about: "It is unexpected to have increased interest in mathematics about me; I already like to deal with mathematics problems."

Undergraduate primary school education students' opinions regarding the factors affecting their achievement in mathematics courses were presented in Table 3.

Table 3. Undergraduate primary school students' opinions regarding factors affecting their achievement in the mathematics courses

\begin{tabular}{llll}
\hline Factors & & f & \% \\
\hline Positive & Lecturer & $\mathbf{3 7}$ & $\mathbf{2 9}$ \\
& Prior Knowledge & 7 & 6 \\
& Personal & 22 & 16 \\
& Time devoted to study & 8 & 7 \\
& Interest in mathematics & 6 & 5 \\
& & 2 & 2 \\
\hline \multirow{2}{*}{ Negative } & Lecturer & $\mathbf{9 6}$ & $\mathbf{7 1}$ \\
& Pedagogical knowledge & 34 & 25 \\
& Content knowledge & 26 & 18 \\
& Prior Knowledge & 8 & 7 \\
& Weak prior learning & 31 & 24 \\
& Prejudice & 25 & 19 \\
& Content & 6 & 5 \\
& Difficult topics & 27 & 20 \\
& Professional incompatibility & 17 & 13 \\
& Personal & 10 & 7 \\
& Time devoted to study & 4 & 3 \\
& Mathematics anxiety & 3 & 2
\end{tabular}

Students underlined such significant factors affecting their achievement in mathematics courses as prior knowledge (40\%), lecturer(s) (31\%), and content coverage (20\%). Moreover, lecturers' pedagogical knowledge was the main barrier for students to achieve the mathematics courses. 6 percentage of the students stated that instruction was the primary factor that contributed their success. Moreover, they mentioned that instructor tended to teach mathematics lessons for every level, understandable and clear, and this ensures the success. The below quotation from s25 indicated lecturer's adequacy in teaching: "Our instructor provided detailed explanations for the problems solved in the classroom with an intelligible language and asks related questions in exams. He did not ask what he did not teach. His only purpose was to evaluate our knowledge." On the other hand, 18 percentages of the students indicate that lecturer was not sufficient in teaching and explaining topics, and some students said that instructor did not have sufficient field knowledge and that is why they were not successful. For example s55 claimed that "I find Mathematics II course difficult and when our instructor passes course subjects quickly like we know everything; it makes me become estranged from course. I barely passed this course.".

Prior knowledge was the other attributed factor for achievement in undergraduate mathematics courses. While 16 percentages of students, who underlined factors related to prior knowledge, stated that they became more successful by putting more on their pre-learned mathematics knowledge, 19 percent of them stated that because they did not have sufficient fundamental of mathematics from the past, they were experiencing failure on further educational levels. For example, this can be seen in the following responses: 
"Mathematics course we are taking in here was part of my friend's high school education. Since I graduated from vocational high school, I don't have prior knowledge about topics and because of that I had difficulties." (s68)

"I was successful because I have solid fundamental. Thanks to our mathematics instructor, it gets better." (s33)

Students who highlighted content of the course as their reason for failure not stated the course they had but stated that mathematics is generally difficult and they showed their negative perception on mathematics and its nature. Additionally, as the change in their interest towards mathematics, participants stated that content coverage of the mathematics courses was unnecessarily difficult for primary school teacher education program, and this fact decreased their success in these courses (7\%). S23 explained course content's relation with success on course as "Mathematics I was fine, also a bit easy, but integral and graphics of functions were very hard on Mathematics II." S104's explanation is as follow: "I am a "same-weighted" student, it is ok but topics from Mathematics II are not the ones I will transfer to children when teaching. I don't know if this is a prejudice but I will fail on final." In addition, personal factors that were affecting students' achievement in mathematics included the time devoted to study mathematics, interest in mathematics and mathematics anxiety.

Table 4 includes the distribution of undergraduate students' views regarding possible contribution of undergraduate mathematic courses to their professional development.

Table 4. Undergraduate primary school students' perceptions on basic mathematic courses' contributions on their profession

\begin{tabular}{llll}
\hline Expectations & Reasons & $\mathbf{f}$ & \% \\
\hline It will contribute & & & \\
& Self-improvement & 28 & 23 \\
& Real life & 4 & 3 \\
& Gaining different perspective & 1 & 1 \\
& Developing abstract thinking skill & 30 & 25 \\
& Pedagogical content knowledge & 16 & 13 \\
\hline
\end{tabular}

\section{Partial contribution}

$\begin{array}{lll}\text { Pedagogical content knowledge } & 8 & 7\end{array}$

Personal development $\quad 2 \quad 1$

\section{It will not contribute}

$\begin{array}{lll}\text { Pedagogical content knowledge } & 25 & 21\end{array}$

Professional competency $\quad 3 \quad 2$

Self-improvement $\quad 2 \quad 2$

\begin{tabular}{lrr}
\hline Overall & 119 & 100 \\
\hline
\end{tabular}

According to the table 4, most of the students viewed mathematics courses as a beneficiary tool (67\%) for their professional development while 25 percentages of them disagreed the need for these mathematics courses in their profession. Twenty-three percent of the students, who thought mathematic courses would have positive effect in their profession as a teacher, stated that mathematics courses would have positive effects on their daily life as well. Statements included, "...of course it will have contributions. Mathematics moderating every aspect of our daily life, even we do not accept this fact. Though I still could not figure out how we use this Mathematics II in daily life." (s22).

Moreover, one-fourth of the students believed that undergraduate mathematics courses would contribute to their teacher career since they could use their mathematical knowledge they had deepen through these course. Besides, some students stated that they would become more competent teachers because of mathematics courses they had received. Some statements were as follows: "of course it will have contributions because mathematics is one of the most necessary lesson that I will teach my students." (s67)

Additionally, students underlined that undergraduate mathematics courses were not well compatible with the primaryschool student level for mathematics, and they mentioned that there was no contribution from these courses to their professional development. Accordingly, S34 used the following statement: "...Clearly, I don't think that it will contribute, because when I become a teacher I will teach to primary-school students. I don't think that I have to teach them the concepts of trigonometry or functions." 


\section{Discussion and Conclusion}

The present study aimed to investigate undergraduate primary school teacher education students' perceptions of basic mathematics courses in terms of difficulty level of the courses, students' attribution of the changes in their interest and achievement in these courses, and need for the mathematics courses in their future profession as a primary school teacher. The study is being limited with the views of undergraduate students who were participated to the study and to the data that were collected through the instrument conducted in the study.

The results obtained in the study indicated that nearly half of the undergraduate students faced a mathematics course curriculum with an unexpected level of difficulty (more or less difficult than they expected), while the others stated that they faced mathematics course curriculum at a difficulty level that they had expected. This situation is not surprising because almost all of the students in this study stated that they had not do any research or reading about mathematics course content, which in turn may cause for them to have different expectations from the actual content of the course. Students related their attributions with lecturer's pedagogical and content knowledge, their past experiences relating mathematic such as prior knowledge and ongoing failure and especially content coverage. The study also indicated that students, who had expected to face an easy course and who experienced a difficult one, explained their astonishment with the content density of the mathematics course in their program. In this connection primary-school undergraduate students carried the belief that they were going to teach less difficult topics in primary school level so the content of the courses had to be less difficult and they did not need advanced level of mathematics in their profession. This argument raises questions such as "Are we required to have more or deeper knowledge should in the subject that we teach?". This fact also has an important share of expectancies regarding difficulty level of the mathematics courses. In addition, another important cause for having low or high expectations regarding difficulty level of the courses is primary-school undergraduate students' prior knowledge on mathematics and the prejudice they develop towards mathematics accordingly. Similarly, Drake, Spillane and Hufferd-Ackles (2001) stated that undergraduate students' opinions and expressions towards mathematics and mathematics course are generally shaped around their previous disappointing and discouraging mathematical experiences. Similarly, Philippou and Christou (1998) conducted a study to explore change of primary-school undergraduate students' attitude towards mathematics courses by their own-developed program, and inspected undergraduate students' attitude towards mathematics when they entered to university. According to the result of their study, negative belief or attitude developed towards mathematics courses in any level of education have significant effect on higher level mathematics education even before taking the course.

Another result of the present study was that the percentage of students who stated a decrease in their interest in mathematics after taking basic mathematics courses was found higher than those who experienced an increase in their interest towards mathematics. This situation might be caused by such factors as instructor's pedagogical and content knowledge, and continuing and increasing failure of undergraduate students in their past mathematical experiences. Moreover, nearly half of the students stated that there was not a significant change in their interest on mathematics and expressed this with their past experiences using expressions like "I already interested in mathematics and it still goes on" or "I have not like mathematics in my past life and I don't like it now." Most undergraduate students, who stated they had increased interest towards mathematics after they took the course, underlined that they had a solid fundamental of mathematics and they were cumulating knowledge on it, so that was why they were successful at mathematics and also interested in it. As stated by Daskalogianni and Simpson (2001), students' pre-university developed attitudes and beliefs towards mathematics can be considered as key elements when transiting them to high school mathematics. Also if there are changes in their interest towards mathematics and when the undergraduate students were asked "what is the reason of this?", they signaled lecturer(s) and content of the course as causes. In addition, lecturers' lack of pedagogical knowledge may cause this due to the fact that lecturers in these courses are most of the case (as the case in our study) from the mathematics department, and their research interest and their teaching activities are usually in mathematics or mathematics education area. Bingolbali and Ozmantar (2009) also stated factors like student's needs and expectation, unique properties of different departments, widely variable needs of different departments and their unique curriculums are affective on instructors lecturing on different departments and these lectures. Accordingly, when the instructor who is giving the mathematics lecture plans his syllabus, including students' expectations, interest and needs on mathematics courses, it would be helpful for students to overcome difficulties related to mathematics (Hart, 2002; Hirst, Meacock \& Ralha, 2004; Perry, 2007).

According to the results, primary-school undergraduate students do not only underline lecturers as their source of failure but also signal lack of their prior knowledge on mathematics and the content coverage of the courses. Especially, lecturers' pedagogical knowledge was the main barrier for students to achieve the mathematics courses. Studies by Kensington-Miller, Sneddon and Stewart (2014), Yoon, Kensington-Miller, Sneddon and Bartholomew (2011) are two examples which provide evidence that lecturers' content knowledge benefits for undergraduate students teaching skills and success. As stated by Darling Hammond (2000) and Wilburne and Long (2010), teachers' content knowledge is a key factor to students' academic success in today's classrooms. In addition, primary-school undergraduate students mentioned their prior knowledge in mathematics as a cause for their attribution for their achievement in and interest towards mathematics. In a supportive way to this study, House (2000) also stated that mathematics related academic background or experiences can be considered as significant arbiters about student's 
success on mathematics. Accordingly, it can be deduced that primary-school undergraduate students who have strong prior knowledge on mathematics are increasing their success by not learning from in-class environment but accumulating on their prior knowledge.

Besides, most primary-school undergraduate students indicated that mathematics courses were valuable for primaryschool educational processes. Undergraduate students' views regarding contribution of the mathematics courses to their profession categorized as personal development, pedagogical content knowledge and professional qualification. Undergraduate students stated that mathematic courses would be beneficiary in improving their quality of daily life since mathematics is a tool for solving issues in real life. Hill et al. (2008) indicate that teachers must be knowledgeable about real-world contexts or real world situations which give relevance and meaning to mathematics. As an example, Sultan and Artzt (2011) and Artzt et al. (2012), stated that "applications to real life" is a key factor for mathematics courses and they used this factor as a dimension of math-n-sight, developed for students to develop into teachers who use student-centered instructional strategies and are able to create lessons. Moreover, some students carried the belief that undergraduate mathematics courses can deepen their mathematical knowledge that they might use in their classes as a teacher. As a negative opinion regarding the contribution of mathematics courses to a primary school teacher, some students underlined that content of the mathematics courses were not well compatible with the primary-school student level; they might not teach most of the content (such as functions) of these courses to their clients; so there was no contribution from these courses to their professional development. Correlatively as in first question of this study which regarding students' perceptions about difficulty level of the undergraduate mathematics courses, undergraduate primary school students' negative evaluates about contributions of the mathematics courses to their profession might stem from the fact that undergraduate students also carried the belief that primary school teachers do not need advanced level of mathematics in their profession since they will become a primary school teacher that requires (according to them) basic mathematics skills too. This argument raises the questions "What level of content knowledge should teachers have?" and "Are teachers required to have more or deeper knowledge in the subject that they teach?". Pre-service programs and professional development opportunities often focus on developing teachers' knowledge of and skill in understanding students' work and thinking. For an example according to Kahan, Cooper and Bethea (2003), when professional mathematicians consider the problems of school teaching and learning, they frequently conclude that students would learn more in a subject if their teachers knew more in that subject. Similarly, National Commission on Mathematics and Science Teaching for the 21st Century (2000) agrees, high quality teaching requires that teachers have a deep knowledge of subject matter.

As a result of this study, it can be concluded that undergraduate primary-school students studying at the department of primary school teaching do not carry out any preliminary research in the transition from high school to college for the courses which they will encounter in their undergraduate education. Within the scope of this study, it can be said that this situation has a direct impact on students' perceptions of difficulty regarding the basic mathematics courses. Besides, the same situation is thought to have an indirect impact on students' level of the interest and achievement for mathematics and through perceptions of difficulty. Furthermore, the results indicated that undergraduate primary school students pointed out such factors as lecturer's pedagogical and content knowledge level, positive or negative math experiences and lack of prior knowledge for mathematics with regards to the influence of perception and attitude towards mathematics courses. In line with these results, it can be asserted that to carry successful mathematics education not only level of the content knowledge but also lecturer's pedagogical competencies are important. However, it can be said that inadequate or incomplete education in mathematics courses taken before undergraduate degree, especially during primary school, directly affects the following stages of education. Because this research shows that undergraduate primary-school students studying at the department of primary school teaching attached perceptions of difficulty or loss of interest and achievement towards mathematics to adverse past mathematics experiences and deficient prior knowledge that arose as a result of inadequate training. Therefore, starting from preschool and primary school, a sensitive approach should be adopted for mathematics education for all the stages of education. Another important finding of the study is that teacher candidates studying at the department of primary school teaching expressed their unsuccessful math experiences while referring to negative perceptions and expressed their success in mathematics courses while referring to positive perceptions. It's quite important that preparing classroom climates and activities in which students can experience the joy of achievement and having the teachers show the necessary sensitivity to this issue in terms of students' success in the future and positive perceptions intended for mathematics courses are especially of great importance.

Thinking that the primary school teacher is the most important role model for children at the primary school age, it can be said that teachers' approaches and attitudes for their courses may affect the students' perceptions and beliefs about these courses. The mathematics course is thought to be a hard one especially for primary grade students. A failure in this course can cause a weakness on self-efficacy beliefs of students regarding mathematics. When primary school teacher candidates graduate with positive perceptions for mathematics, mathematics courses and teaching mathematics; they can raise students who are successful and confident in mathematics and like mathematics. As stated by Harper and Daane (1998), the quality of instruction in schools depends on positive perceptions about the teaching of 
courses, as well as the proficiency of content education and professional teaching knowledge courses taken by the teacher candidates during their undergraduate education.

\section{Recommendations}

While this study attempted to describe and discuss the participants' expectations and experiences in mathematics courses, future studies can explore undergraduate primary-school students' further expectations and suggestions about the content of these courses at the undergraduate level thoroughly to obtain more in-depth information. In addition, possible relationships between different variables can be examined such as teacher candidates' mathematics selfefficacy beliefs, attitudes and perceptions towards mathematics courses and mathematics achievement levels.

\section{References}

Alkan, V. (2009). The relationship between teaching strategies and styles and pupils' anxiety in mathematics at primary schools in Turkey (Unpublished doctoral dissertation). University of Nottingham.

Arnon, S., \& Reichel, N. (2007). Who is the ideal teacher? Am I? Similarity and difference in perception of students of education regarding the qualities of a good teacher and of their own qualities as teachers. Teachers and Teaching: Theory and Practice, 13(5), 441-464.

Artzt, A. F., Sultan, A., Curcio, F. R., \& Gurl, T. (2012). A capstone mathematics course for prospective secondary mathematics teachers. Journal of Mathematics Teacher Education, 15(3), 251-262.

Baki, A. (2014). Kuramdan uygulamaya matematik egitimi [Mathematics education from theory into practice]. Ankara: Harf Egitim Yayıncılık

Baykul, Y. (2014). Ilkokulda matematik ogretimi [Mathematics education in primary school]. Ankara: Pegem Akademi

Beswick, K. (2012). Teachers' beliefs about school mathematics and mathematicians' mathematics and their relationship to practice. Educational Studies in Mathematics, 79(1), 127-147.

Bingolbali, E., Monaghan, J., \& Roper, T. (2007). Engineering students' conceptions of the derivative and some implications for their mathematical education. International Journal of Mathematical Education in Science and Technology, 38(6), 763-777.

Bingolbali, E., \& Ozmantar, M. F. (2009). Factors shaping mathematics lecturers' service teaching in different departments. International Journal of Mathematical Education in Science and Technology, 40(5), 597-617.

Boz, N. (2008). Turkish pre-service mathematics teachers' beliefs about mathematics teaching. Australian Journal of Teacher Education, 33(5).

Britton, S., New, P.,Sharma, M., \& Yardley, D. (2005). A case study of the transfer of mathematics skills by university students. International Journal of Mathematical Education in Science and Technology, 38, 13.

Charalambos, C., Philippou, G., \& Kyriakides, L. (2002). Towards understanding teachers' philosophical beliefs about mathematics. Paper presented at the International Group for the Psychology of Mathematics Education (PME), Norwich UK.

Charalambous, C., Panaoura, A., \& Philippou, G. (2009). Using the history of mathematics to induce changes in preservice teachers' beliefs and attitudes: insights from evaluating a teacher education program. Educational Studies in Mathematics, 71(2), 161-180.

Clarkson, P.C., Bishop, A., FitzSimons, G., \& Seah, W. (2000). Challenges and constraints in researching values. In J.Bana \& A.Chapman (Eds.), Mathematics education beyond 2000 (pp. 188-195). Perth: Mathematics Education Research Group of Australasia.

Cooke, A. \& Hurst, C. (2013). Relationships between mathematics anxiety, confidence to teach mathematics, and attitudes towards mathematics in pre-service teachers. Paper presented at CIEAEM 65, Turin, Italy, 22-26 July, 2013.

Darling-Hammond, L. (2000). Teacher quality and student achievement: A review of state policy evidence. Education Policy Analysis Archives, 8(1).

Daskalogianni, A., \& Simpson, A. P. (2000). Towards a definition of attitude: the relationship between the affective and cognitive in pre-university students. In Nakahara, T. and Koyama, M. (Eds.), Proc. 24th Conf. of the Int. Group for the Psychology of Mathematics Education (Vol. 2, pp. 217-224). Hiroshima, Japan: PME.

Drake, C., Spillane, J. P., \& Hufferd-Ackles, K. (2001). Storied identities: Teacher learning and subject-matter context. Journal of Curriculum Studies, 33(1), 1-23. 
Eng, T. H., Li, V. L., \& Julaihi, N. H. (2013). Lecturers' perceptions, students' problems and solutions for handling highfailure rate mathematics courses. Procedia-Social and Behavioral Sciences, 90, 853-861.

Ernest, P. (1989a). The knowledge, beliefs, and attitudes of the mathematics teacher: A model. Journal of Education for Teaching, 15, 13-33.

Ernest, P. (1989b). The impact of beliefs on the teaching of mathematics. In P. Ernest (Ed.), Mathematics teaching: The state of the art (pp. 249-254). London: Falmer Press.

Ernest, P. (2000). Teaching and learning mathematics. In V.Koshy, P. Ernest, \& R. Casey (Ed.), Mathematics for primary teachers. London, UK: Routledge.

Flegg, J., D. Mallet, and M. Lupton. (2012). Students' perceptions of the relevance of mathematics in engineering. International Journal of Mathematical Education in Science and Technology. 43(6): 717-732.

Gallagher, A. M., \& Kaufman, J. C. (2005). Gender differences in mathematics: Where we are and what we need to know. In A. M. Gallagher \& J. C. Kaufman (Eds.), Gender differences in mathematics (pp. 316-332). New York, NY: Cambridge University Press.

Grootenboer, P. J. (2003). Facilitating affective change with preservice primary teachers. In L. Bragg, C. Campbell, G. Herbert, \& J. Mousley (Eds.), MERINO: Mathematics education research: Innovations, networking, opportunity (Proceedings of the 26th Annual Conference of Mathematics Education Research Group of Australasia, Vol. 2, pp. 413-420). Geelong, Australia: MERGA.

Guner, N. (2013). Pre-service teachers`metaphors about mathematics. NWSA: Education Sciences, 8(4), 428-440.

Gupta, S., Harris, D. E., Carrier, N. M., \& Caron, P. (2006). Predictors of student success in entry-level undergraduate mathematics courses. College Student Journal, 40(1), 97.

Harper, N. W., \& Daane, C. J. (1998). Causes and reduction of math anxiety in preservice elementary teachers. Action in Teacher Education, 19(4), 29-38.

Harris, D., Black, L., Hernandez-Martinez, P., Pepin, B., Williams, J., \& with the TransMaths Team. (2015). Mathematics and its value for engineering students: what are the implications for teaching?. International Journal of Mathematical Education in Science and Technology, 46(3), 321-336.

Hart, L. C. (2002). Pre-service teachers' beliefs and practice after participating in an integrated content/methods course. School Science and Mathematics, 102(1), 4-15.

Hill, H. C., Blunk, M. L., Charalambous, C. Y., Lewis, J. M., Phelps, G. C., Sleep, L., \& Ball, D. L. (2008). Mathematical knowledge for teaching and the mathematical quality of instruction: An exploratory study. Cognition and Instruction, 26(4), 430-511.

Hirst, K., Meacock, S., \& Ralha, E. (2004). Student expectations of studying mathematics at university. In Proceedings of the 27th Annual Conference of the Mathematics Education Research Group of Australasia (MERGA27) (Vol. 1, pp. 295-302).

House, J.D. (2000). Academic background and self-beliefs as predictors of student grade performance in science, engineering and mathematics. International Journal of Instructional Media, 27(2) 207-220

Kahan, J. A., Cooper, D. A., \& Bethea, K. A. (2003). The role of mathematics teachers' content knowledge in their teaching: A framework for research applied to a study of student teachers. Journal of Mathematics Teacher Education, 6(3), 223-252.

Kandemir, M. (2007). Attitudes and concept learning levels about basic mathematics of class student teachers. Journal of Education Faculty, 9(2), 13-32.

Kensington-Miller, B., Sneddon, J., \& Stewart, S. (2014). Crossing new uncharted territory: shifts in academic identity as a result of modifying teaching practice in undergraduate mathematics. International Journal of Mathematical Education in Science and Technology, 45(6), 827-838.

Merriam, S. B. (1998). Qualitative research and case study applications in education. San Francisco, CA: Jossey-Bass Publishers.

Midgley, C., Feldlaufer, H., \& Eccles, J. S. (1989). Change in teacher efficacy and student self-and task-related beliefs in mathematics during the transition to junior high school. Journal of Educational Psychology, 81(2), 247.

Miles, MB. \& Huberman, AM. (1994). Qualitative Data Analysis (2nd edition). Thousand Oaks, CA: Sage Publications. 
National Commission on Mathematics and Science Teaching for the 21st Century (2000). Before it's too late: A report to the nation from the national commission on mathematics and science teaching for the 21st century. Washington, DC.: Author.

Perry, B. (2007). Australian teacher's views of effective mathematics teaching and learning. ZDM Mathematics Education, 39, 271-286.

Philippou, N. G., \& Christou, C. (1998). The effects of a preparatory mathematics program in changing prospective teachers' attitudes towards mathematics. Educational Studies in Mathematics, 35, 189-206.

Rayner, V., Pitsolantis, N., \& Osana, H. (2009). Mathematics anxiety in preservice teachers: Its relationship to their conceptual and procedural knowledge of fractions. Mathematics Education Research Journal, 21(3), 60-85.

Schuck, S. (1997). Using a research simulation to challenge prospective teachers' beliefs about mathematics. Teaching and Teacher Education, 13,529-539.

Sultan, A., \& Artzt, A. (2011). The mathematics that every secondary math teacher needs to know. Florence, KY: Routledge, Taylor \& Francis Group.

Suresh, R. (2002). Persistence and attrition in Engineering: Understanding the nature of students" experience with barrier courses. PhD. dissertation, University of New York.

Sutherland, R., \& Pozzi, S. (1995). The changing mathematical background of undergraduate engineers. London: Engineering Council.

Thompson, A.G.: 1992, Teachers' Beliefs and Conceptions: A Synthesis of the Research. In D.A. Grouws (Ed.), Handbook of Research on Mathematics Learning and Teaching. New York: Macmillan, 127-146.

Uusimaki, L., \& Nason, R. (2004, July). Causes underlying pre-service teachers' negative beliefs and anxieties about mathematics. In Proceedings of the 28th Conference of the International Group for the Psychology of Mathematics Education (Vol. 4, pp. 369-376).

Van de Walle, J., Karp, K. S., \& Bay-Williams, J. M. (2010). Elementary and middle school mathematics methods: teaching developmentally (7th edition). New York: Allyn and Bacon.

Weber, K. (2004). Traditional instruction in advanced mathematics courses: A case study of one professor's lectures and proofs in an introductory real analysis course. Journal of Mathematical Behavior, 23(2), 115-133.

Wilburne, J. M., \& Long, M. (2010). Secondary pre-service teachers' content knowledge for state assessments: Implications for Mathematics Education Programs. Issues in the Undergraduate Mathematics Preparation of School Teachers, 1.

Yin, R. K. (2003). Case study research: Design and methods (3rd ed.). Thousand Oaks, CA: Sage.

Yoon, C., Kensington-Miller, B., Sneddon, J., \& Bartholomew, H. (2011). It's not the done thing: social norms governing students' passive behavior in undergraduate mathematics lectures. International Journal of Mathematical Education in Science and Technology, 42(8), 1107-1122.

Zevenbergen, R. (2001). Changing contexts in tertiary mathematics: Implications for diversity and equity. In D. Holton (Ed.) The teaching and learning of mathematics at university level, An ICMI study. Dordrecht, The Netherlands: Kluwer Academic Publishers.

Zevenbergen, R. (2005). Primary pre-service teachers' understandings of volume: The impact of course and practicum experiences. Mathematics Education Research Journal, 17(1), 3-23. 